\title{
Application of a Computable General Equilibrium (CGE) Model to Evaluate Surface Water Reallocation Policies
}

\author{
Chang K. Seung, Thomas R. Harris, Jeffrey E. Englin, and \\ Noelwah R. Netusil*
}

\begin{abstract}
This study uses a computable general equilibrium (CGE) model to calculate the economic impacts of reallocating surface water from irrigated agriculture to recreational use at the Stillwater National Wildlife Refuge in Churchill County, Nevada. In this study, we consider three alternative assumptions about how the proceeds from water rights sales are spent. Model results show that under all three alternative assumptions, the combined effect of water rights compensation and the increase in recreation-related expenditures does not offset the reduction in agricultural production.
\end{abstract}

\section{INTRODUCTION}

This study examines the economic impacts of reallocating surface water from irrigated agriculture to recreational use at the Stillwater National Wildlife Refuge in Churchill County, Nevada. We use a standard regional computable general equilibrium (CGE) model and a recreation demand model to calculate the impacts on output, employment, and income. We consider three alternative assumptions about how the proceeds from water rights sales are spent. We found that, under all three alternative assumptions, the combined effect of water rights compensation and the increase in recreation-related expenditures does not offset the reduction in agricultural production.

The Stillwater National Wildlife Refuge wetlands are located in Churchill County, Nevada, which is about 80 miles east of Reno. The study region, Churchill County, contains both the agricultural land from which the surface water will be withdrawn and the Stillwater wetlands to which the surface water will be reallocated. Years of drought during the late 1980s and early 1990s degraded the quality and quantity of water reaching the refuge. This severely impaired fish, upland game, and migratory waterfowl habitat-an important consideration since approximately 30 percent of migratory waterfowl in the western United States feed and rest at Stillwater. In addition to supporting numerous species, Stillwater also provides recreational opportunities, such as bird watching, waterfowl hunting,

\footnotetext{
*Post-Doctoral Research Fellow, Department of Applied Economics and Statistics, University of Nevada, Reno; Professor, Department of Applied Economics and Statistics, University of Nevada, Reno; Professor, Department of Applied Economics and Statistics, University of Nevada, Reno; and Associate Professor, Department of Economics, Reed College, Portland, OR. This research was funded by the University of Nevada Agricultural Experiment Station Projects 5147 and 5149; U.S. Department of Interior Grant \#1425-97-CS-20-20005; the University of Nevada Foundation; and U.S. Department of Commerce, Economic Development Administration, University Center for Economic Development Grant \#07-06-03262-98.
} 
and camping. Estimated visitation at Stillwater has ranged from 28,000 to 40,000 visits annually.

There exists a rich body of literature, including numerous state and regional economic impact studies of water management in western states, which addresses the trade-offs from alternative water policies. Classic examples include Seckler (1971), Hamilton, Barranco, and Walker (1982), and Hamilton and Pongtanakorn (1983). More recent studies include Berck, Robinson, and Goldman's (1991) investigation of water reallocation in the South San Joaquin Valley, California, and Seung, Harris, and MacDiarmid's (1998a) study of the economic impacts of a water reallocation policy in rural Nevada using two alternative regional impact models.

Total agricultural output in the Churchill County economy in 1992 was about $\$ 39.40$ million, or about 6.9 percent of the economy's total output of $\$ 570.45$ million (Nevada Agricultural Statistical Service 1995). Major agricultural sectors are the livestock, other crops, and hay sectors, which produce about 4.6 percent, 0.6 percent, and 1.7 percent of the economy's total output, respectively. Total nonagricultural output in the economy in 1992 was about $\$ 531.05$ million, or about 93.1 percent of the economy's total output (Alward et al. 1992).

To evaluate the impacts of reallocating water from agriculture to the wetlands at Stillwater, we consider the following three effects: (1) the reduction in agricultural production; (2) the change in income to land from compensation for water rights; and (3) the increase in recreation-related expenditures due to increased recreation activities at Stillwater. We specify three alternative assumptions about how the proceeds from water rights sales are spent.

\section{MODEL DESCRIPTION}

\section{A. Churchill County CGE Model}

\section{Production}

There are three agricultural sectors in our CGE model. The sectors are the livestock, other crops, and hay sectors. These sectors use as primary inputs labor, capital, land, and water. The intermediate inputs are used in fixed ratios to output. The livestock sector uses as major intermediate inputs other crops and hay. Most of the intermediate demand of the livestock sector for the other crops and hay is satisfied by imports. As the water rights to the surface water are transferred from the other crops sector and hay sector to recreational use at Stillwater, land use in these two sectors will be proportionally reduced because water rights are appurtenant to the land and there is no crop substitution. It is not likely in Churchill County that farmers faced with reduction in agricultural water will substitute hay and other crops for higher-valued crops such as vegetables because of significant obstacles to be overcome. For example, farmers would have to develop a network for marketing high-value vegetables; a skilled agricultural 
labor market would have to be created for vegetables; there are frequently high winds in the agricultural area in the study region, which is not appropriate for vegetable production; and there are early and late freezes to which vegetables are especially vulnerable (Sunding 1996).

Production technology in an agricultural sector is described by a quadruplenested production function (Figure 1). First, acreage and water are combined in fixed ratios to "produce" land. Second, capital and land are combined via a constant elasticity of substitution (CES) function to "produce" a capital-land aggregate. Third, labor and the capital-land aggregate are combined via another CES function to "produce" the value added. Finally, intermediate inputs are combined in fixed ratios to produce output. By nesting the structure of the agricultural production technology this way, the present model allows greater flexibility in specifying the elasticities of input substitution for the primary inputs than a simple four-input Cobb-Douglas or CES value-added function. In our CGE model, both labor and capital are allowed to change in response to reduction in land use (water withdrawal), and are substitutable for land.

FIGURE 1

Production Technology, Agricultural Sectors

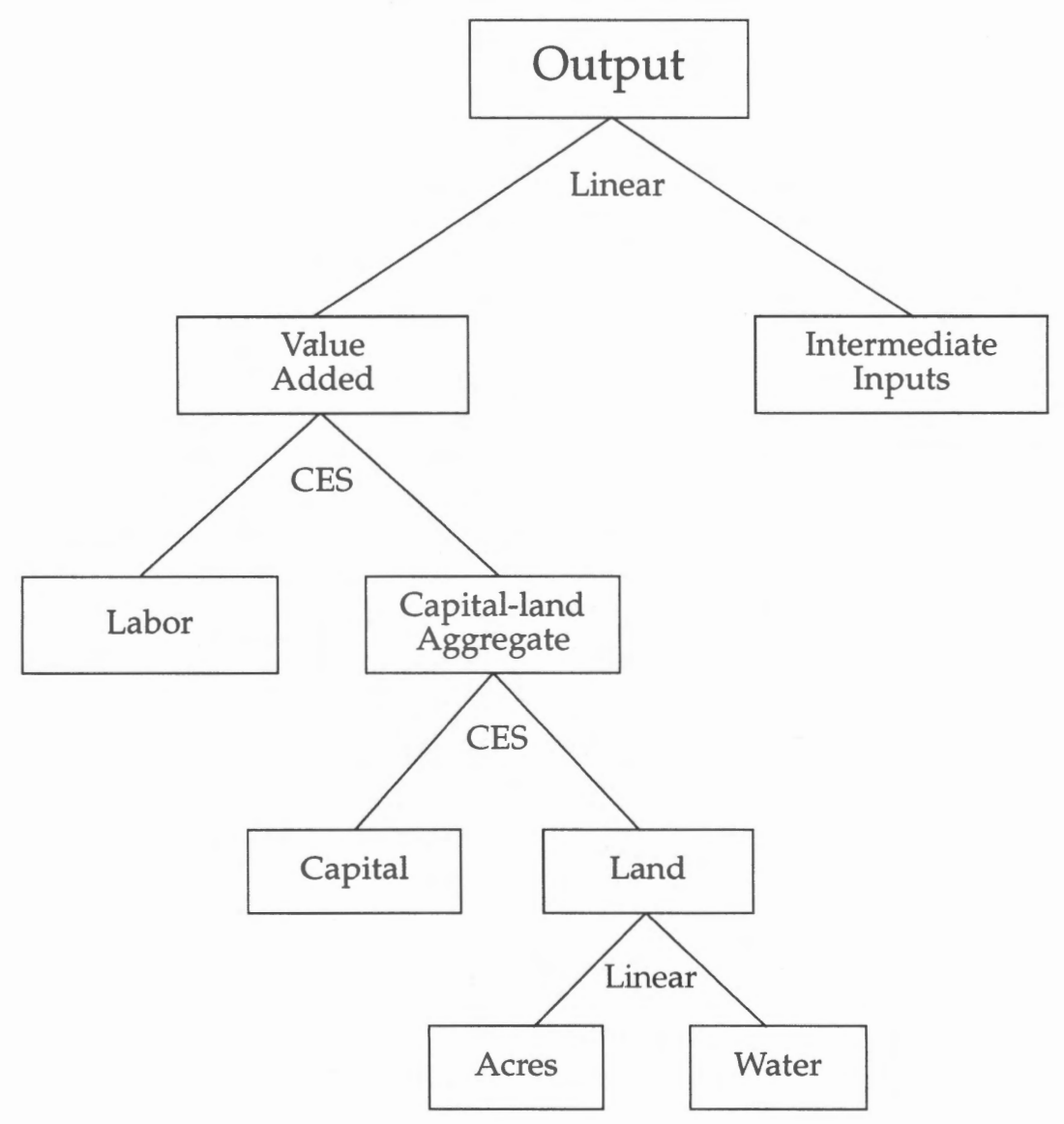


There are five nonagricultural sectors in this study. The sectors are (1) mining; (2) construction, manufacturing, transportation, communication, and public utilities (CMTCPU); (3) trade; (4) finance, insurance, and real estate (FIRE); and (5) services. The nonagricultural sectors use labor, capital, and intermediate inputs. Production technology in the nonagricultural sectors is described by a doublenested production function. First, labor and capital are combined via a CES function to produce the value added. Second, intermediate inputs are combined in fixed ratios to produce output.

\section{Compensation for Water Rights}

In Churchill County, landowners hold the water rights. When water rights are sold, the landowners are compensated for these water rights. We specify three alternative scenarios for modeling how proceeds from water rights sales will be spent in the county and incorporated into the CGE model.

Scenario 1: In this scenario, we assume that all the proceeds from water rights sales leave the study region. The proceeds are used to retire debt or to purchase outside consumer goods. Therefore, for Scenario 1, none of the proceeds are spent in Churchill County.

Scenario 2: In this scenario, we assume that only 50 percent of the proceeds leave the study region for payment of debt or consumption of outside goods. Landowners save their remaining proceeds in a savings account, which generates interest income to the landowners. Therefore, income to land from the sale of water rights is the (reduced) rental income from land plus the interest income from savings.

Scenario 3: This scenario is similar to Scenario 2. The only difference is that all the proceeds remain within Churchill County in Scenario 3 while only 50 percent of the proceeds remain in the county in Scenario 2.

The income to land with the sale of water rights is calculated as:

$$
\mathrm{NY}=\sum_{\mathrm{ag}} \mathrm{RN}_{\mathrm{ag}} \mathrm{N}_{\mathrm{ag}}+(\text { inr })(1-\mathrm{wclkr})\left(\mathrm{P}_{\mathrm{w}}\right) \mathrm{AF},
$$

where NY is income to land; $\mathrm{RN}_{\mathrm{ag}}$ and $\mathrm{N}_{\mathrm{ag}}$ are return to land and land use in the agricultural sector (ag), respectively; inr is the interest rate; wclkr is the water compensation leakage rate; $P_{w}$ is the price per acre-foot of water; and AF is the amount of water rights sold. Here, $P_{w}$ is the price of an acre-foot of water delivered in perpetuity, not the annual cost of leasing the water for a year. The parameter wclkr in Equation 1 is set equal to 1, 0.5, and 0 for scenarios 1, 2, and 3, respectively.

\section{Consumption}

Households are grouped into three types. They are: (1) high-income; (2) medium-income; and (3) low-income households. Preferences of the households are represented by a CES utility function. Utility maximization for each type of 
household subject to its budget constraint yields the demand function for each good.

\section{Factor Market}

Cost minimization for each sector's production yields its conditional factor demand function for each factor of production. There are two types of labor in our study-agricultural labor and nonagricultural labor. Agricultural labor is mobile among the three agricultural sectors and nonagricultural labor is mobile among the five nonagricultural sectors. Labor migrates in response to wage changes, though the elasticity is less than unity. Capital is mobile both intersectorally and interregionally. Land in each agricultural sector is fixed at the baseyear level before policy implementation and at the reduced level with the policy.

\section{B. Recreation Demand Model}

The recreation demand model in this study consists of two participation equations estimated for northern Nevada. These equations describe the relationship between the number of recreation visitors and acres of wetlands at Stillwater. The Nevada Division of Water Planning maintains data for the number of days spent angling, hunting, and participating in general recreation (bird watching, camping, etc.) at Stillwater. Information on the annual acres of wetlands at Stillwater and the breeding population estimates for total ducks is collected by the U.S. Fish and Wildlife Service (Henry 1998). For the statistical analysis, the angler data was combined with the general recreation data since anglers, in addition to fishing, were found to participate in activities categorized as "general recreation." Two participation equations were estimated using the linear probability model:

$$
\begin{aligned}
& \log \left(\frac{P_{h}}{1-P_{h}}\right)=\beta_{11}+\beta_{12} A C R E+\beta_{13} A_{C R E}{ }^{2}+\beta_{14} \text { DUCK (Hunting Rate) } \\
& \log \left(\frac{P_{g}}{1-P_{g}}\right)=\beta_{21}+\beta_{22} A C R E+\beta_{23} A_{C R E}{ }^{2}, \quad \text { (General Recreation Rate) }
\end{aligned}
$$

where $P_{h}$ and $P_{g}$ are the proportions of the northern Nevada population who participate in hunting and general recreation, respectively; ${ }^{1} \mathrm{ACRE}$ is acres of wetlands at Stillwater; DUCK is breeding population estimates of ducks; and $\beta_{\mathrm{ij}}{ }^{\prime} \mathrm{s}$ are parameters to be estimated. In Equations 2 and $3, P_{h}$ and $P_{g}$ are sampled over time. To calculate the predicted participation rates, Equation 2 and Equation 3 are solved for $\mathrm{P}_{h}$ and $\mathrm{P}_{\mathrm{g}}$, respectively.

Clearly, there are a number of factors that affect recreational use of Stillwater. We are unable to address most of these factors due to data limitations. Nevertheless, it seems likely that the key feature driving recreational use of the refuge is acreage. We have hypothesized a nonlinear relationship between refuge

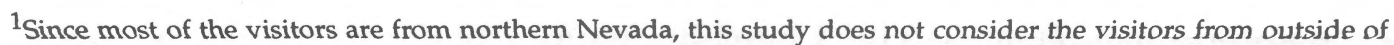
northern Nevada. 
size and recreational use implying that use will increase with increases in wetland acreage up to a point. After that point, the wetland becomes less attractive. This occurs because of a decline in the number of places to hunt and engage in general recreation since many locations would be under water and access would be limited. This has occurred at Stillwater during flood years.

Table 1 provides the results of our analysis. The signs of the estimated coefficients presented in Table 1 conform to expectations. All coefficients except one are significant at the $1 \%$ level. The $\mathrm{ACRE}^{2}$ coefficient in the hunting equation is significant at the $10 \%$ level. The hunting rate is positively influenced by the number of acres at Stillwater, but as more acres are added this effect diminishes. The number of ducks positively impacts the hunting participation rate. The general recreation rate is also positively influenced by the number of acres at Stillwater, again at a diminishing rate. These equations can be simulated to generate the expected participation rate for these two activities for any wetland acreage at Stillwater.

TABLE 1

Parameter Estimates for Participation Equations

\begin{tabular}{lcc}
\hline & Hunting Rate & General Recreation Rate \\
\hline Constant & $-9.39^{* * *}$ & $-2.35^{* * *}$ \\
& $(-1.38)$ & $(0.13)$ \\
ACRE & $0.21 \mathrm{E}-3^{* * *}$ & $0.83 \mathrm{E}-4^{* * *}$ \\
& $(0.85 \mathrm{E}-4)$ & $(0.22 \mathrm{E}-4)$ \\
& $-0.46 \mathrm{E}-8^{*}$ & $-0.21 \mathrm{E}-8^{* * *}$ \\
ACRE2 & $(0.27 \mathrm{E}-8)$ & $(0.72 \mathrm{E}-9)$ \\
& $0.11^{* * *}$ & \\
DUCK & $(0.04)$ & \\
& 0.67 & 0.52 \\
\hline
\end{tabular}

*Significant at the $10 \%$ level.

*** Significant at the $1 \%$ level.

Note: Numbers in the parentheses are standard errors.

On-site surveys were conducted to determine the expenditure patterns of visitors at Stillwater. From these surveys, the distribution of trip expenditures made within Churchill County for the trade sector (gasoline, food, and supplies) and the services sector (lodging) was estimated. Per capita hunter expenditures per day for the trade and services sectors are estimated to be $\$ 37.18$ and $\$ 0.65$, respectively. The per capita general recreator expenditures per day are estimated to be $\$ 20.90$ and $\$ 0.36$ for the trade and service sectors, respectively. Per capita hunter and general recreator expenditures for the service sector (lodging) are very small. The reason is that most of the visitors are one-day-trip visitors, who do not stay in a motel or hotel. The per capita hunter and per capita general recreator trade sector expenditures, $\$ 37.18$ and $\$ 20.90$, are expenditure values margined at 25.5 percent (Fletcher et al. 1997), and represent the amount of the trade sector expenditures that remains in the Churchill County economy. 


\section{EMPIRICAL IMPLEMENTATION}

\section{A. Data and Calibration}

This study used IMPLAN (IMpact analysis for PLANning) data. IMPLAN has two components-the database and the software. The database provides the information needed for making regional economic accounts, such as a social accounting matrix (SAM). The software is an algorithm to solve an input-output model. In this study, IMPLAN is used only to generate the Churchill County SAM (Tables A1 and A2 in the Appendix), not to solve an input-output model. The 528 sectors in the Churchill County SAM are aggregated into the eight sectors in this study (Table A3 in the Appendix).

TABLE 2

Parameter Values used in Churchill County CGE Model

\begin{tabular}{|c|c|}
\hline Elasticities/Parameters & Values \\
\hline \multicolumn{2}{|c|}{ Elasticity of Substitution in Production ${ }^{\mathrm{a}}$} \\
\hline Agricultural sectors & $\sigma_{\mathrm{LJ}}{ }^{1}=$ \\
\hline Nonagricultural Sectors & 0.8 \\
\hline \multicolumn{2}{|c|}{ Elasticity of Substitution in Consumption ${ }^{\mathrm{b}}$} \\
\hline Low-Income Households & 0.750 \\
\hline Medium-Income Households & 1.125 \\
\hline High-Income Households & 1.500 \\
\hline \multicolumn{2}{|c|}{ Elasticity of Substitution between Imports and Local Goods ${ }^{c}$} \\
\hline Agricultural Goods & 3.500 \\
\hline Mining & 0.500 \\
\hline $\mathrm{CMTCPU}^{3}$ & 2.868 \\
\hline Trade, FIRE, ${ }^{4}$ and Services & 2.000 \\
\hline
\end{tabular}

Elasticity of Transformation in Production: Domestic Goods and Exports ${ }^{\mathrm{d}}$

Agricultural Goods

Mining and CMTCPU 3

Trade, FIRE, ${ }^{4}$ and Services

Factor Shares in Agricultural Sectors ${ }^{e}$

Labor

Capital

Land

Labor Migration Elasticity $f$

aThe positive values of the elasticities of substitution, 0.7 for labor and capital and 0.3 for capital and land, are from Boyd and Newman (1991). The value of the elasticity of substitution between labor and capital, 0.7, is larger than the central estimate for agriculture of 0.61 in de Melo and Tarr $(1992$, p. 232). The elasticity of substitution between labor and capital used in nonagricultural sectors, 0.8, is based on de Melo and Tarr (1992, p. 232).

bThe elasticities of substitution for low- and high-income households are from Shoven and Whalley (1984, p. 1011). We set the elasticity of substitution for medium-income households at the average value of the elasticities for low- and high-income households.

cSince a locally produced agricultural good and its imported version are highly substitutable, we set the elasticity of substitution for imports and local goods at a high value of 3.5 for agricultural goods. The elasticities of substitution for the other sectors are based on de Melo and Tarr (1992, p. 231).

$\mathrm{d}$ The elasticities of transformation are based on de Melo and Tarr (1992, p. 233).

eThe factor shares for agriculture are from Robinson, Kilkenny, and Hanson (1990). These shares are compared with those used in Boyd and Newman (1991), who used about 0.27, 0.36, and 0.37 for labor, capital, and land shares, respectively, for the livestock sector. They used very similar factor shares for all the other agricultural sectors.

The labor migration elasticity is from Plaut (1981).

${ }^{1} \sigma_{\mathrm{LJ}}$ denotes the elasticity of substitution in agricultural production between labor and the capital-land aggregate.

${ }^{2} \sigma_{\mathrm{KN}}$ denotes the elasticity of substitution in agricultural production between capital and land.

${ }_{3}^{3}$ MMTCPU denotes Construction, Manufacturing, Transportation, Communication, and Public Utilities.

${ }^{4}$ FIRE denotes Finance, Insurance, and Real Estate. 
Calculating the effects of policy changes in a CGE model requires specific parameter values for the model equations. Some parameters, such as elasticities of substitution and elasticities of transformation, are specified on the basis of econometric research. The remaining parameters, such as share parameters, are then determined by solving the model equations with the base-year observations for model variables and the exogenous parameters substituted in the model. Table 2 presents values of major parameters and elasticities used in our CGE model.

\section{B. Simulations}

\section{Reduction in Land Use}

We assume that 30,000 acre-feet of surface water from the other crops and hay sectors are reallocated to recreational use at the Stillwater refuge. Using the water budget for the Carson Division developed by MacDiarmid (1988), we calculated water and acreage available in agriculture and at the wetlands both before the water reallocation and after the water reallocation. Table 3 presents the results. The table shows that with a reduction of 30,000 acre-feet of surface water in agriculture, the total available water in agriculture would decline from 95,554 acrefeet to 65,554 acre-feet. The irrigated acreage in the other crops and hay sectors will decline from 25,825 acres to 17,717 acres. This behavior represents about a 31.4 percent decrease in total land use in the other crops and hay sectors. We assume that land uses in the other crops and hay sectors are reduced by the same percentage (31.4 percent).

TABLE 3

Water and Acreage Available in Agriculture and Wetlands

\begin{tabular}{|c|c|c|}
\hline & $\begin{array}{l}\text { Before } \\
\text { Water Reallocation }\end{array}$ & $\begin{array}{l}\text { After } \\
\text { Water Reallocation }\end{array}$ \\
\hline Diversion (A) & 169,723 (acre-feet) & 169,723 (acre-feet) \\
\hline Transportation Loss (B) & 74,169 (acre-feet) & 74,169 (acre-feet) \\
\hline Water Rights Acquisition (C) & 0 (acre-feet) & 30,000 (acre-feet) \\
\hline Farm Delivery (D = A-B-C) & 95,554 (acre-feet) & 65,554 (acre-feet) \\
\hline Farm Delivery Per Acre (E) & 3.7 (acre-feet/acre) & 3.7 (acre-feet/acre) \\
\hline Irrigated Acreage $(\mathrm{F}=\mathrm{D} 4 \mathrm{E})$ & 25,825 (acres) & 17,717 (acres) \\
\hline Wetlands Transfer Rate $(G)^{a}$ & 0.81 & 0.81 \\
\hline Wetlands Delivery $(\mathrm{H}=\mathrm{G} \times \mathrm{C})$ & 0 (acre-feet) & 24,243 (acre-feet) \\
\hline Drainage to Wetlands (I) & 42,999 (acre-feet) & 29,499 (acre-feet) \\
\hline Total Wetlands Inflow $(\mathrm{J}=\mathrm{H}+\mathrm{I})$ & 42,999 (acre-feet) & 53,742 (acre-feet) \\
\hline Water Requirement at Wetlands (K) & 3.42 (acre-feet/acre) & 3.42 (acre-feet/acre) \\
\hline Wetlands Acreage $(\mathrm{L}=\mathrm{J} 4 \mathrm{~K})$ & 12,573 (acres) & 15,714 (acres) \\
\hline
\end{tabular}

aWetlands transfer rate of 0.81 is calculated as the use rate of 2.99 acre-feet per acre in agriculture divided by the farm delivery of 3.7 acre-feet per acre.

Note: The numbers presented in this table are calculated based on MacDiarmid (1988).

Water Rights Compensation

In an earlier study of the economic impacts of a water rights acquisition program for Churchill County, Nevada, Sunding (1996) calculated the average 
price per acre-foot of water to be $\$ 471$ for 30,000 acre-feet of water sold. We use this information to calculate the total amount of water rights compensation. The total amount of compensation for 30,000 acre-feet of water rights is calculated to be approximately $\$ 14.13$ million. We use the three scenarios mentioned earlier to examine how the model results change. For this analysis, we assume an annual interest rate of 5 percent for the landowners' savings.

\section{Recreation-Related Expenditure}

With 30,000 acre-feet of agricultural water reallocated to Stillwater, the total wetland inflow would increase from 42,999 acre-feet to 53,742 acre-feet (Table 3 ). The wetland acreage would increase from 12,573 acres to 15,714 acres. With an increase in wetland acreage, there will be an increase in the number of visitors and in recreation-related expenditures. We calculated the change in the number of recreators and the recreation-related expenditures using the participation equations and the on-site surveys on expenditure behavior of the Stillwater wetlands visitors. ${ }^{2}$ We found that the increase in the wetland acreage will cause the total number of hunters and general recreators to increase from 83,661 to 90,810 , or by about 8.5 percent compared to the base year. Total recreation-related expenditures for the trade and service sectors are found to increase by about $\$ 191,000$ (from $\$ 1.920$ million to $\$ 2.111$ million), or by about 9.9 percent compared to the base year. However, the increase in total recreation-related expenditures is very small compared to the size of the Churchill County economy; the increase in total recreation-related expenditures of $\$ 191,000$ is only about 0.03 percent of the baseyear value of the total output in the Churchill County economy. Therefore, the increases in the recreation-related expenditures are not expected to generate noticeable economic impacts.

In calculating the economic impacts, we treat as exogenous shocks the reduction in agricultural land use in other crops and hay sectors and the increases in recreation-related expenditures. We run a simulation experiment for the base run and for each of the three scenarios described earlier.

\section{Discussion of Results}

Table 4 presents the impacts of reallocating 30,000 acre-feet of water from irrigated agriculture to the Stillwater wetlands. The table shows that as water is withdrawn from the other crops and hay sectors, the output in these sectors decreases by about 28.67 percent and 29.86 percent, respectively, in Scenario 1 . Scenarios 2 and 3 report similar impacts on output in the other crops and hay sectors.

\footnotetext{
${ }^{2}$ The following steps are taken to calculate the changes in recreation visitor days and changes in regional recreation expenditures. The first step is to solve Equations 2 and 3 for participation rates $\left(\mathrm{P}_{h}\right.$ and $\left.\mathrm{P}_{\mathrm{g}}\right)$ with acres of wetlands set at the before-policy level. The second step is to multiply the participation rates by the northern Nevada population to calculate the before-policy numbers of hunters and general recreators. The third step is to solve equations 2 and 3 for calculating the after-policy participation rates $\left(P_{h}\right.$ and $\left.P_{g}\right)$ with acres of wetlands now set at the after-policy level. The fourth step is to multiply the after-policy participation rates by the northern Nevada population to calculate the after-policy numbers of hunters and general recreators. The fifth step is to calculate the changes in the numbers of hunters and general recreators using the information from the second and the fourth steps. The final step is to translate the changes in the numbers of hunters and general recreators into the changes in recreation expenditures using the on-site surveys of visitors' expenditure.
} 
Livestock production increases slightly in all scenarios. This is explained as follows. The reduction in water leads to an increase in hay and other crop prices at the regional level. This increases the feed cost in the livestock sector, reducing the value-added price of livestock. On the other hand, demand for labor in the livestock sector increases with a reduction in the wage for labor. In this study, the reduction in labor cost (wage) offsets the increase in the feed cost. This results in an increase in livestock output. Table 4 also shows that all the scenarios report similar impacts in total agricultural output, employment, and value added. Total agricultural output, employment, and value added decrease by about 8.98 percent, 3.96 percent, and 12.08 percent, respectively, for all three scenarios. Overall, the agricultural impacts are not sensitive to alternative assumptions pertaining to expenditure patterns of water rights sales.

TABLE 4

Economic Impacts of Water Reallocation (percentage change)

\begin{tabular}{lccc}
\hline & Scenario 1 & Scenario 2 & Scenario 3 \\
\hline Output & & & \\
Livestock & 1.13 & 1.12 & 1.12 \\
Other crops & -28.67 & -28.67 & -28.66 \\
Hay & -29.86 & -29.86 & -29.86 \\
Total agricultural output & -8.98 & -8.98 & -8.98 \\
Total nonagricultural output & -0.18 & -0.17 & -0.15 \\
Total Regional Output & -0.98 & -0.97 & -0.96 \\
Employment & & & \\
Agriculture & -3.96 & -3.96 & -3.96 \\
Nonagriculture & -0.15 & -0.13 & -0.11 \\
Total & -0.36 & -0.35 & -0.33 \\
Capital & & & \\
Agriculture & -12.78 & -12.76 & -12.76 \\
Nonagriculture & -0.39 & -0.37 & -0.34 \\
Total & -1.13 & -1.11 & -1.08 \\
Value Added & & & \\
Agriculture & -12.08 & -12.08 & -12.08 \\
Nonagriculture & -0.29 & -0.26 & -0.23 \\
Total & -1.05 & -1.02 & -1.00 \\
Income to Land & -10.84 & -7.04 & -3.24 \\
Household Income & & & \\
Low-income household & -1.15 & -0.96 & -0.76 \\
Medium-income household & -1.01 & -0.85 & -0.69 \\
High-income household & -0.95 & -0.81 & -0.66 \\
Total & -0.99 & -0.84 & -0.68 \\
Labor Migration & & & \\
Agricultural labor & -21 & -21 & -21 \\
Nonagricultural labor & -13 & -11 & -10 \\
Total & -34 & -32 & -31 \\
\hline
\end{tabular}

However, the impacts on income to land are significantly different among the three scenarios (Table 4). Scenario 1 reports the largest decrease (10.84 percent) in the income to land. Scenarios 2 and 3 report smaller decreases in the income to land than Scenario 1, with income to land decreasing by about 7.04 percent and 3.24 percent in Scenarios 2 and 3, respectively. Impacts from Scenarios 2 and 3 
differ from those in Scenario 1 because in Scenarios 2 and 3, a portion of the water rights sale proceeds remains in the study region, and generates interest income to the landowners. Model results imply that, in all three scenarios, the price per acrefoot of water (\$471) is too low to compensate the landowners for their lost income. Even in Scenario 3, where all the proceeds remain within the study region, the assumed price per acre-foot of water $(\$ 471)$ is not high enough to compensate for the lost income to the landowners.

Although not reported in this table, the lost income of the landowners is exactly compensated for in Scenario 3 if the price per acre-foot of water is set at $\$ 669.93 .^{3}$ The price per acre-foot of water that exactly compensates the landowners for their lost income changes if different values of interest rates are assumed or if the amount of the water rights purchase changes. Assuming all the proceeds from water rights sales remain in the study region (Scenario 3), we calculated the prices per-acre foot of water required to leave the income to land unchanged from its base-year level for different amounts of water rights acquisition. The results are presented in Figure 2. The figure indicates that as the amount of water rights acquisition increases, the per acre-foot price of water should increase to leave income to land unchanged. For example, the per acre-foot price of water should be at least $\$ 727.59$ for a sale of 70,000 acre-feet of water rights for the income to land to be equal to or greater than the pre-policy income (Figure 2). The curve in Figure 2 is upward sloped for the following reason. As water rights sales increase, land use will decrease. This means that the value of the marginal product of water (land) will increase. As the value of the marginal product of water (land) increases, the farmers will require a higher price for an acre-foot of water.

The reduction in total agricultural value added and income to land causes household income to decrease. Table 4 shows that the largest decrease in total household income is reported by Scenario 1, in which all the proceeds from water rights sales leave the study region. As household income decreases, households spend less on nonagricultural goods. This leads to a reduction in nonagricultural production; total nonagricultural output decreases by about 0.18 percent, 0.17 percent, and 0.15 percent in Scenarios 1, 2, and 3, respectively.

As output is reduced in the other crops and hay sectors, some labor is released from these sectors. Some of this released labor is either employed in the other agricultural sector (livestock sector) or out-migrates to the rest of the United States. All the scenarios report that the net out-migration of agricultural labor is about 21 full- and part-time jobs (Table 4). Net out-migration of nonagricultural labor is about 13, 11, and 10 full- and part-time jobs in Scenarios 1, 2, and 3, respectively. Table 4 also shows that agricultural capital is reduced by about 13 percent in all the scenarios. Nonagricultural capital decreases slightly in all the scenarios.

\footnotetext{
${ }^{3}$ The annualized value of the price per acre-foot of water is calculated to be $\$ 33.50$. This value is very similar to what we calculated for another study. In a water reallocation study for the Walker River Basin of Nevada and California (Seung, Harris, and MacDiarmid, 1998b), we calculated the annualized price per acre-foot of water to be about $\$ 33.10$. However, these values ( $\$ 33.50$ and $\$ 33.10$ ) are low compared to Berck, Robinson, and Goldman (1991), in which the annual payment per acre-foot of water is calculated to be about $\$ 67$ for a 50 percent reduction in agricultural water use.
} 
FIGURE 2

Income-compensating Price of Water

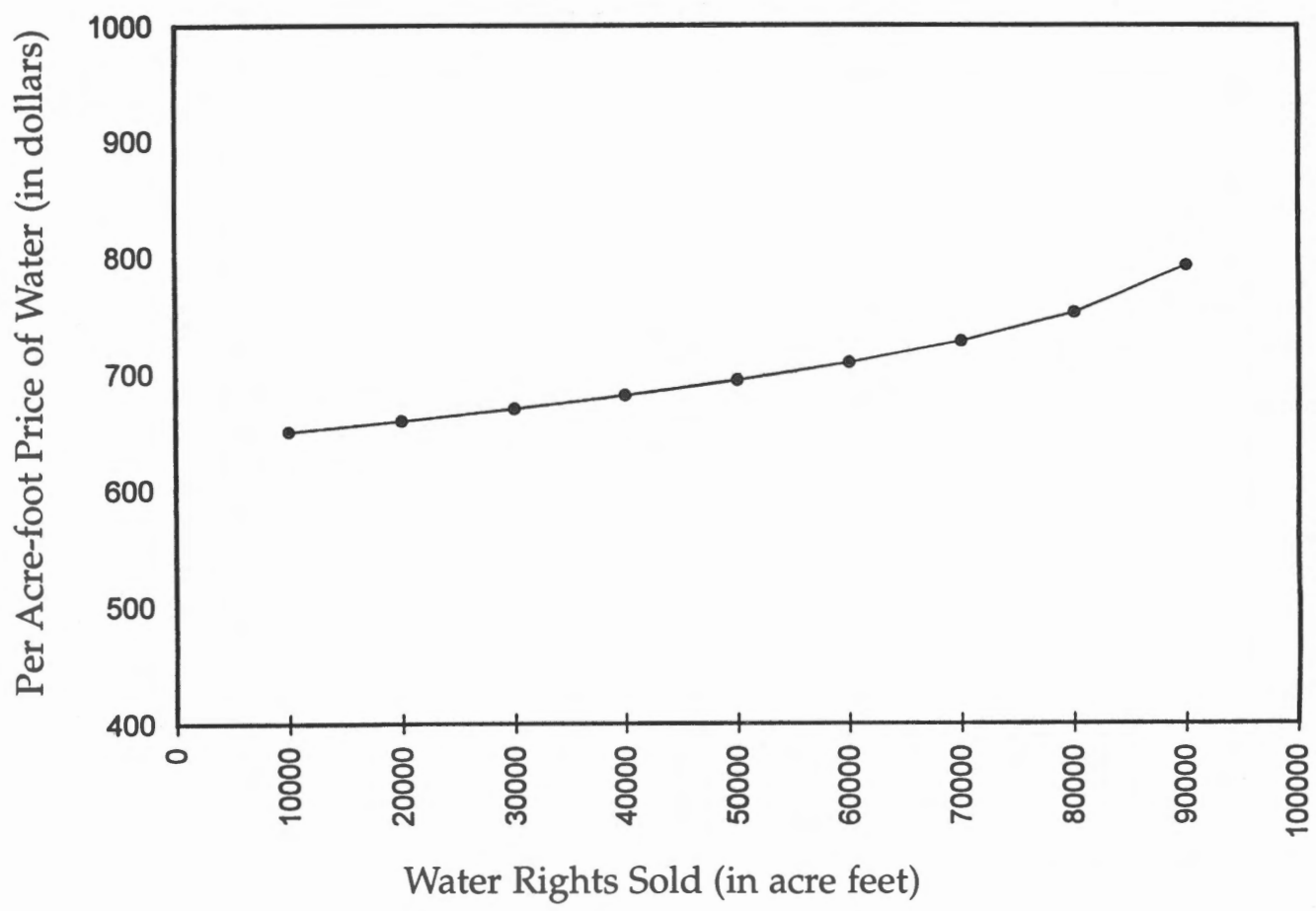

Total regional capital is reduced by about 1.1 percent. Total regional output decreases by approximately 0.98 percent, 0.97 percent, and 0.96 percent in scenarios 1,2, and 3, respectively. This implies that in all three scenarios, the combined effect of water rights compensation and the increase in recreation-related expenditures does not offset the reduction in agricultural production due to the reallocation of surface water.

\section{CONCLUSION}

In this study, we used a regional CGE model and a recreation demand model to calculate the economic impacts of reallocating surface water from irrigated agriculture to recreational use at the Stillwater National Wildlife Refuge in Churchill County, Nevada. In calculating the impacts, we considered the reduction in agricultural production, water rights compensation, and the increase in recreation-related expenditures. We specified three alternative assumptions about how the proceeds from water rights sales are spent-(1) all the proceeds from water rights sales leave the study region; (2) 50 percent of the proceeds leave the region; and (3) all the proceeds remain within the region. We compared the results from the alternative assumptions.

Major findings from this study are the following. First, the policy impacts on agricultural output and employment are not sensitive to the alternative assumptions about the expenditure patterns of water rights sales. However, the impacts on income to land and those on household income change drastically 
depending on the alternative assumptions. Also, the impacts on nonagricultural variables are more or less sensitive to the alternative assumptions.

Second, all three scenarios result in a price per acre-foot of water $(\$ 471)$ that is not high enough to compensate the landowners for their lost income from selling their water rights for 30,000 acre-feet of water. We found that a per acrefoot price of water of $\$ 669.93$ exactly compensates the landowners for their lost income in Scenario 3, in which all the proceeds from water rights sales remain within the study region. These results are obtained assuming that the land released from agricultural production can not find alternative use. However, if it is assumed that the released land can find alternative use, then the per acre-foot price of water will be lower than $\$ 669.93$ and the per acre-foot price of water (\$471) calculated by Sunding (1996) could be quite adequate to compensate the landowners for their lost income. Finally, total regional output decreases in all three scenarios. This implies that the combined effect of water rights compensation and the increase in recreation-related expenditures does not offset the reduction in agricultural production.

We suggest several directions for future research. First, this study employed three alternative scenarios for modeling how water rights compensation is spent. It would be useful in a future study to conduct a survey on the behavior of the landowners with water rights compensation, and to refine these scenarios based upon the survey data for doing more detailed analysis of the policy impacts. Second, the model used in this study can not capture the substitution of existing irrigation technology for a water-conserving technology. For a future study, it would be very useful to develop a model based on previous studies, such as Green et al. (1996) and Caswell and Zilberman (1985), in which change in irrigation technology is allowed in response to reduced water in agriculture. 
152 Seung, Harris, Englin \& Netusil The Review of Regional Studies 1999, 29(2)

\section{APPENDIX}

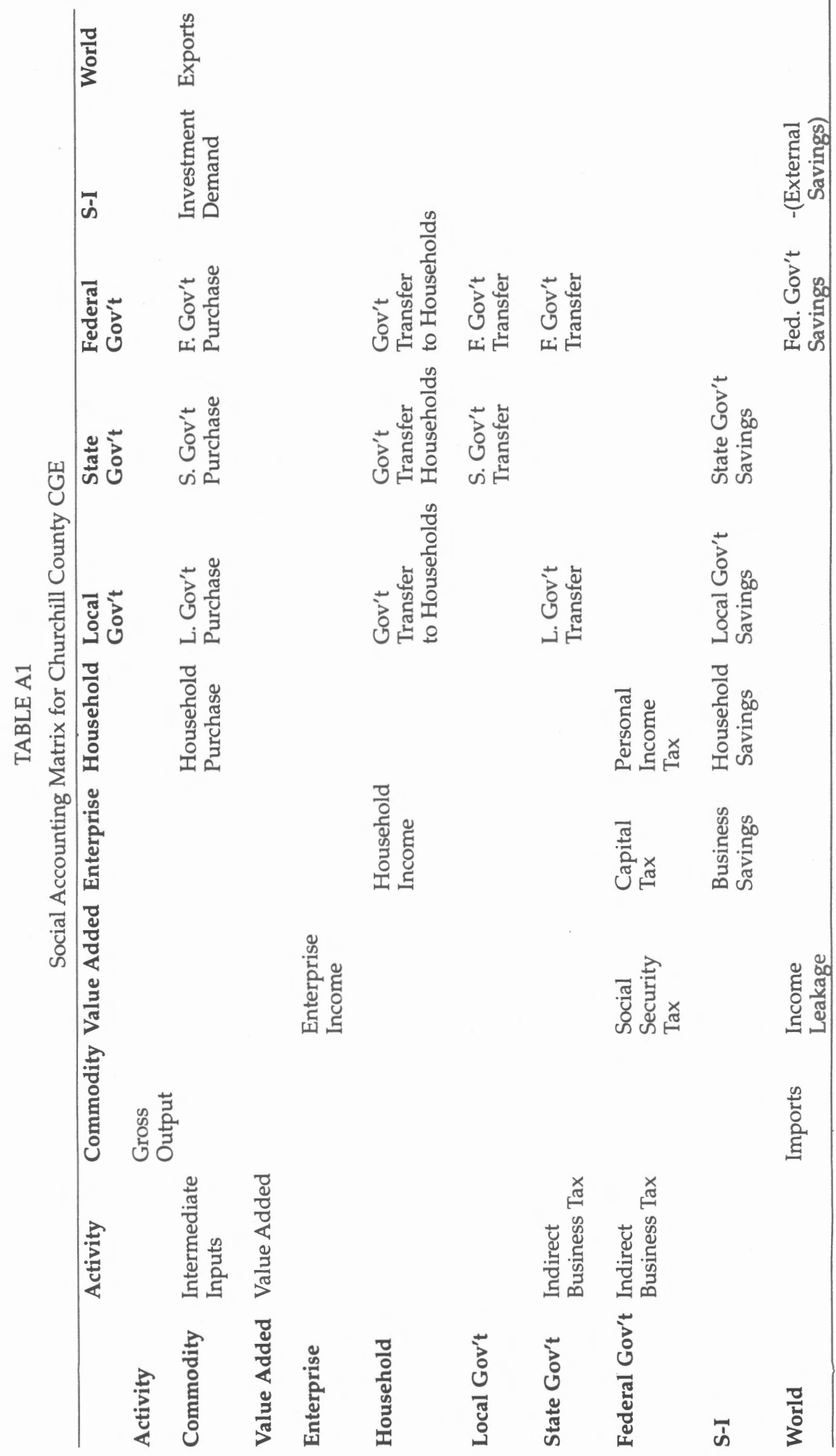




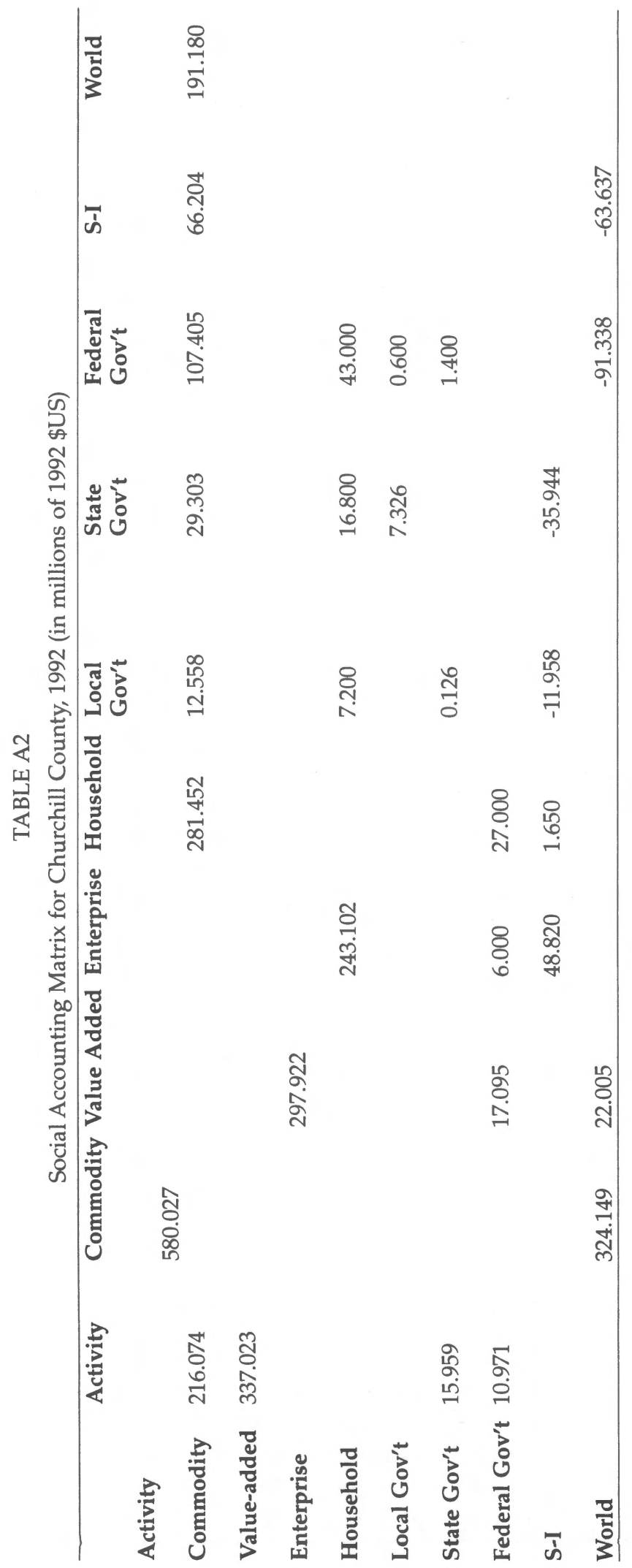


TABLE A3

Sector Aggregation Scheme for Churchill County CGE Model

\begin{tabular}{|c|c|}
\hline $\begin{array}{l}\text { IMPLAN } \\
\text { Sectors }\end{array}$ & $\begin{array}{l}\text { Sectors in } \\
\text { Churchill County CGE Model }\end{array}$ \\
\hline Sectors 1-9 & Livestock \\
\hline Sectors $10-12$ and Sectors $14-27$ & Other Crops \\
\hline Sector 13 & Hay and Pasture \\
\hline Sectors $28-47$ & Mining \\
\hline Sectors $48-446$ & $\begin{array}{l}\text { Construction, Manufacturing, Transportation, } \\
\text { Communication, and Public Utilities }\end{array}$ \\
\hline Sectors $447-455$ & Trade \\
\hline Sectors $456-462$ & Finance, Insurance, and Real Estate \\
\hline Sectors $463-528$ & Services \\
\hline
\end{tabular}

\section{REFERENCES}

Alward, G., E. Siverts, C. Taylor, and S. Winter. "Micro IMPLAN, User's Guide, Version 91-F." Fort Collins, Colorado: USDA Forest Service, Land Management Planning Systems Group, 1992.

Berck, P., S. Robinson, and G. Goldman. "The Use of Computable General Equilibrium Models to Assess Water Policies." In A. Dinar and D. Zilberman (eds.) The Economics and Management of Water and Drainage in Agriculture. Norwell, MA: Kluwer Academic Publishing, 1991.

Boyd, R., and D. Newman. "Tax Reform and Land-Using Sectors in the U.S. Economy: A General Equilibrium Analysis." American Journal of Agricultural Economics 73 (May 1991), 398-409.

Caswell, M., and D. Zilberman. "The Choices of Irrigation Technologies in California." American Journal of Agricultural Economics 67 (May 1985), 223-234. de Melo, J., and D. Tarr. A General Equilibrium Analysis of U.S. Foreign Trade Policy. Cambridge, MA: MIT Press, 1992.

Fletcher, R., G. Borden, T. Harris, D. Taylor, and B. Moline. "Economic Impacts and Trade-Offs from Public Land Grazing on Local Communities." 1997 Society of Range Management Annual Meetings, Rapid City, SD, February 18, 1997.

Green, G., D. Sunding, D. Zilberman, and D. Parker. "Explaining Irrigation Technology Choices: A Microparameter Approach." American Journal of Agricultural Economics 78 (November 1996), 1064-1072.

Hamilton, J., and C. Pongtanakorn. "The Economic Impact of Irrigation Development in Idaho: An Application of Marginal Input-Output Models." Annals of Regional Science 17 (1983), 60-69.

Hamilton, J., G. Barranco, and D. Walker. "The Effect of Electricity Prices, Lift, and Distance on Irrigation Development in Idaho." American Journal of Agricultural Economics 64 (May 1982), 280-285. 
Henry, W. Facsimile transmission to the Authors. March 12, 1998.

MacDiarmid, T. "An Economic Analysis of the Efficiency Target Policy for the Carson Diversion on the Newlands Project." Unpublished Thesis, University of Nevada, Reno, 1988.

Nevada Agricultural Statistical Service. "Nevada Agricultural Statistics 1994-1995." 1995.

Plaut, T. "An Econometric Model for Forecasting Regional Population Growth." International Regional Science Review 6 (1981), 53-70.

Robinson, S., M. Kilkenny, and K. Hanson. "The USDA/ERS Computable General Equilibrium (CGE) Model of the United States." U.S. Department of Agriculture, Economic Research Service Staff Report No. AGES 9049. Washington, D.C., 1990.

Seckler, D. (ed.) California Water: A Study in Resource Management. Berkeley, CA: University of California Press, 1971.

Seung, C., T. Harris, and T. MacDiarmid. "Economic Impacts of Surface Water Reallocation Policies: A Comparison of Supply-Determined SAM and CGE Models." Journal of Regional Analysis and Policy 27 (2) (1998a), 55-76. . "Economic Impacts of Water Reallocation: A CGE Analysis for Walker River Basin of Nevada and California." Unpublished manuscript, 1998b.

Shoven, J., and J. Whalley. "Applied General-Equilibrium Models of Taxation and International Trade: An Introduction and Survey." Journal of Economic Literature 22 (1984), 1007-1051.

Sunding, D. "Economic Impacts of USFWS' Water Rights Acquisition Program for Lahontan Valley Wetlands." Appendix 6 in Water Rights Acquisition for Lahontan Valley Wetlands, Churchill County, Nevada, Final Environmental Impact Statement, Vol. 2, Appendix. Portland, OR: U.S. Department of the Interior, Fish and Wildlife Service, Region 1, September 1996. 
